\title{
ANÁLISE DE CONTEÚDO DE LIVROS DIDÁTICOS DE BIOLOGIA: UMA PERSPECTIVA SOBRE OS TEMAS BIOTECNOLOGIA E ENGENHARIA GENÉTICA NO ENSINO MÉDIO
}

\section{CONTENT ANALYSIS OF TEXTBOOK'S BIOLOGY: A PERSPECTIVE ON THE TOPICS BIOTECHNOLOGY AND GENETIC ENGINEERING IN HIGH SCHOOL}

\author{
E. J. F. Chaves, M. de F. Camarotti
}

Universidade Federal da Paraíba

E-mail: chavesjf@gmail.com,fcamarotti@yahoo.com.br

\section{Resumo}

No que se refere ao conteúdo de Biotecnologia e Engenharia genética nos livros didáticos de Biologia, muitas vezes este é o único e melhor material didático disponível para o aluno. Esse trabalho tem como importância definir a qualidade do conteúdo referente ao tema Biotecnologia e Engenharia genética nos livros didáticos de Biologia dentre aqueles presentes no guia do PNLD/2012. Foram analisados sete livros didáticos quanto aos tipos de enfoques veiculados ao tema supracitado. Foi utilizada a análise de conteúdo a partir da análise temática para estabelecer os tipos de enfoques. Dentre os livros analisados, quatro apresentaram os três indicadores de enfoques, e apenas um, mostrou maior destaque, apresentando discussões melhor elaboradas a respeito de questionamentos éticos.

Palavras-chave: ensino de biologia. biotecnologia. engenharia genética. livro didático.

\begin{abstract}
With regard to the content of Biotechnology and Genetic Engineering in textbooks of biology, often this is the single best teaching materials available to the student. This work is important to define the quality of the content related to the theme Biotechnology and Genetic Engineering in textbooks of biology among those present in the guide PNLD/2012. Seven textbooks were analyzed for the types of approaches conveyed to the above theme. It used the content analysis from the thematic analysis to establish the types of approaches. Among the books analyzed, four presented the three indicators of approaches, and only one showed more prominent, with better elaborate discussions about ethical questions.
\end{abstract}

Keywords: biology education. biotechnology. genetic engineering. textbook. 


\section{INTRODUÇÃO}

Antes de o homem entender os processos que levaram ao desenvolvimento da biotecnologia ele já a utilizava para produzir diversos produtos de seu interesse, tal como vinhos e pães (BOREM, 2005). Atualmente, a biotecnologia abrange diversas áreas de conhecimento que decorre da ciência básica, ciência aplicada, e de outras tecnologias, e tem sido vista como uma forma de aplicar ciência em beneficio do homem e da sociedade, e é entendida como uma atividade multidisciplinar, podendo ser dividida de duas formas - Biotecnologia tradicional e Biotecnologia moderna - de acordo com as técnicas utilizadas (MALAJOVICH, 2011; FIGUEIREDO; PENTEADO; MEDEIROS, 2006). A biotecnologia tradicional é constituída de um determinado conjunto de técnicas que utilizam seres vivos encontrados na natureza ou até mesmo melhorados pelo homem a fim de exercer determinada função produtiva (FIGUEIREDO; PENTEADO; MEDEIROS, 2006). Tais técnicas correspondem ao isolamento, à seleção a olho nu e os cruzamentos genéticos naturais entre espécies compatíveis; a fermentação por microrganismos como, por exemplo, a produção de antibióticos, álcool combustível, vinho, cerveja e outrem (CARVALHO, 1996; SILVEIRA; FUTINO; OLALDE, 2002). Já a biotecnologia moderna utiliza de técnicas não naturais de seleção, transformação genética e otimização metabólica em organismos vivos naturais para obter outros organismos vivos não encontrados na natureza - engenharia genética (FIGUEIREDO; PENTEADO; MEDEIROS, 2006). Os Parâmetros Curriculares Nacionais para o Ensino Médio (PCNEM) conferem a Biotecnologia ao ensino de Biologia, que por sua vez está inserida na área de "Ciências da Natureza, Matemática e suas Tecnologias" (BRASIL, 2000). A tecnologia neste âmbito permite contextualizar os conhecimentos, permitindo ao jovem contemporâneo compreender a tecnologia como um processo de conexão por diversos conhecimentos e suas aplicações tecnológicas. No que se refere ao conteúdo de Biotecnologia e Engenharia genética nos livros didáticos (LD) de Biologia, muitas vezes este é o único e também o melhor material didático disponível para o aluno, principalmente os da rede pública de ensino (IBGE, 1982). Portanto, os conhecimentos sobre este tema, quando presentes no livro didático, auxiliam o trabalho docente e, principalmente, permitem ao aluno ser introduzido no debate das implicações intelectuais, técnico, éticas, políticas e 
econômicas da Biotecnologia e Engenharia genética na sociedade. Sendo assim, o objetivo desse trabalho foi verificar os livros didáticos de Biologia utilizados no ensino médio no que se refere aos tipos de enfoques referentes aos temas Biotecnologia e Engenharia genética.

\section{PERCURSO METODOLÓGICO}

\subsection{Tipo de pesquisa}

Foi utilizada a metodologia segundo Silva e Carvalho (2012), que por sua vez foi inspirada na pesquisa qualitativa da Análise de Conteúdo de Bardin (2011), a fim de estabelecer os tipos de enfoques veiculados sobre os temas Biotecnologia e Engenharia Genética, nos livros didáticos selecionados. As metodologias qualitativas apresentam um foco na interpretação que os próprios integrantes têm da situação sob estudo, em vez da quantificação; ênfase no entendimento e não num objetivo predeterminado e certa preocupação com o contexto (MARCONI; LAKATOS, 2010). A pesquisa bibliográfica é desenvolvida com base em material já elaborado, constituído principalmente de artigos científicos e livros, tratando-se do levantamento e seleção da bibliografia sobre o assunto que está sendo pesquisado (GIL, 2002). O método de pesquisa descritivo por sua vez, pretende descrever os fatos e fenômenos de determinada realidade (TRIVIÑOS, 1987).

A Análise Temática foi selecionada como metodologia para análise de conteúdo. A Análise Temática é uma das formas que melhor se adequa a investigações qualitativas, que por sua vez apresenta três etapas que constituem a aplicação desta metodologia de análise: 1) Préanálise; 2) Exploração; 3) Tratamento dos resultados e interpretação (BARDIN, 2011). A Análise Temática consiste principalmente em descobrir os núcleos de sentido que compõem a comunicação e cuja presença de aparição pode significar alguma coisa para o objetivo analítico escolhido (BARDIN, 2011). 


\subsection{Objeto de estudo}

Para realização do estudo foram selecionadas as obras didáticas de Biologia aprovadas e presentes no guia do Programa Nacional do Livro Didático (PNLD/2012) como também as obras didáticas de Biologia mais utilizadas no estado da Paraíba. Dentre as coleções selecionadas, o critério de presença de objeto de estudo - que no caso dessa pesquisa foram os temas Biotecnologia e Engenharia genética - no LD foi tido como critério de seleção. Os livros didáticos selecionados estão apresentados a seguir:

1. LOPES, S; ROSSO, S. Bio. v.2. São Paulo: Saraiva, 2010.

2. AMABIS, J. M.; MARTHO, G. R. Biologia das populações. v.3. São Paulo: Moderna, 2009.

3. BIZZO, N. Novas bases da Biologia: O ser humano e o futuro. v.3. São Paulo: Ática, 2012.

4. LINHARES, S; GEWANDSZNADJER, F. Biologia Hoje. v.3. São Paulo: Ática, 2011.

5. SANTOS, F. S; AGUILAR, J. B. V; OLIVEIRA, M. M .A. de. Biologia: Ser Protagonista Biologia. v.3 São Paulo: Edições SM, 2010.

6. PEZZI, A. C; GOWDAK, D, O; MATTOS, N. S. Biologia: Citologia, Embriologia e Histologia. v.1. São Paulo: FTD, 2010.

7. MENDONÇA, V; LAURENCE, J. Biologia. v.3. São Paulo: Nova Geração, 2010.

Após o contato com a Secretaria de Estado da Educação da Paraíba, tomou-se ciência que as escolas da rede estadual da Paraíba utilizavam duas obras específicas que continham os temas Biotecnologia e Engenharia Genética - dentre aquelas aprovadas e distribuídas pelo PNLD/2012 - são elas:

1. LOPES, S; ROSSO, S. Bio. v.2. São Paulo: Saraiva, 2010.

2. AMABIS, J.; MARTHO, G. Biologia das populações. v.3. São Paulo: Moderna, 2009. 


\subsection{Procedimentos metodológicos}

A fim de estabelecer os enfoques relacionados aos temas Biotecnologia e Engenharia genética nos LD selecionados, foi realizada uma leitura flutuante [8] das obras selecionadas e em seguida elaborada uma lista de termos-chave referente aos temas Biotecnologia e Engenharia genética. No Quadro 1 estão listados os termos-chave encontrados nos livros didáticos analisados após realização da leitura flutuante.

Quadro 1. Termos-chave encontrados após realizar a leitura flutuante nos livros didáticos selecionados.

\begin{tabular}{|l|l|l|l|}
\hline $\begin{array}{l}\text { Manipulação do } \\
\text { DNA }\end{array}$ & Código genético & Biossegurança & Engenharia genética \\
\hline Biblioteca de DNA & Vacina gênica & Nanotecnologia & $\begin{array}{l}\text { Aconselhamento } \\
\text { genético }\end{array}$ \\
\hline Clonagem de DNA & Generapia & Produção agrícola & Hibrido \\
\hline DNA fingerprint & Genética molecular & Vacina & Células-tronco \\
\hline Análise de DNA & Genoma & Embrapa & Laboratório \\
\hline DNA & Genes & CTNBio & - \\
\hline DNA recombinante & Transgênicos & Biologia molecular & - \\
\hline Vacina de DNA & Clonagem de plantas & Enzimas de restrição & - \\
\hline Religião & Clonagem de animais & Biotecnologia & - \\
\hline Ética & Clonagem terapêutica & OGM & - \\
\hline Moral & Clonagem molecular & Anticorpo & - \\
\hline Ecoética & $\begin{array}{l}\text { Clonagem de seres } \\
\text { humanos }\end{array}$ & Antibiótico & - \\
\hline Bioética & Clonagem & Cromossomos & - \\
\hline Terapia gênica & Proteoma & Diagnóstico & - \\
\hline Análise genética & Amniocentese & Melhoramento & - \\
\hline Clonagem gênica & Aborto terapêutico & PGH & - \\
\hline Genética Clássica & Célula vegetal & PCR & - \\
\hline Genômica & In vitro & Eletroforese & - \\
\hline $\begin{array}{l}\text { Manipulação } \\
\text { genética }\end{array}$ & Microrganismo & Insulina & - \\
\hline & \multicolumn{2}{|c|}{ Fonte: dados da investigação, 2014. } & \\
\hline
\end{tabular}

Tendo os termos chave listados, foram estabelecidas categorias de análise para cada livro didático (capítulos ao qual o tema analisado estava inserido), e que por sua vez - tais categorias - abrangem codificações e descrições para os termos-chave. Para isso, foi utilizado um conjunto de elementos que auxiliaram na análise dos textos no que se refere à 
compreensão dos núcleos de sentidos da mensagem de cada unidade de registro. Os elementos utilizados estão descritos a seguir, baseados em Bardin (2011):

- $\quad$ Unidade de contexto (categoria): unidade de compreensão para codificar a unidade de registro e corresponde ao segmento da mensagem, cujas dimensões são superiores às da unidade de registro.

- Unidade de registro (UR): unidade de significação a codificar, que corresponde ao segmento de conteúdo considerado como unidade base para a categorização.

- Termo-chave: termos que se encontram presentes nas unidades de registro e servem para selecionar tais unidades.

As categorias formadas estão descritas a seguir:

- $\quad$ Engenharia genética;

- Biotecnologia moderna;

- Biotecnologia moderna aplicada na saúde;

- Metodologia técnico-científica utilizada em Biotecnologia moderna e Engenharia genética;

- Biossegurança;

- Questões éticas;

Por seguinte, foi feito um agrupamento dessas categorias e assim foi possível originar três indicadores de enfoques: 
1. Enfoque relacionado às tecnologias de manipulação do DNA: nesse indicador estão inclusas as categorias Engenharia genética, Biotecnologia moderna, Metodologia técnico-científica utilizada em Biotecnologia moderna e Engenharia genética.

2. Enfoque relacionado às questões éticas: nesse indicador estão inclusas as categorias Biossegurança e Questões éticas.

3. Enfoque relacionado à genética humana e saúde: nesse indicador está inclusa apenas a categoria Biotecnologia moderna aplicada na saúde.

\section{RESULTADOS E DISCUSSÃO}

Foi encontrado um total de 1.249 unidades de registros. Tais resultados estão apresentados no Quadro 2.

Quadro 2. Unidades de registro estabelecidos após análise de conteúdo dos livros didáticos selecionados.

\begin{tabular}{|c|c|c|c|}
\hline Livro didático & Categoria & $\begin{array}{l}\text { Quantidade } \\
\text { de unidade } \\
\text { de registro }\end{array}$ & Total \\
\hline \multirow{5}{*}{$\begin{array}{c}\text { Bio v.2 } \\
\text { Lopes e Rosso, } 2010\end{array}$} & Engenharia Genética & 98 & \multirow{5}{*}{299} \\
\hline & Biotecnologia moderna & 135 & \\
\hline & Biotecnologia moderna aplicada à saúde & 22 & \\
\hline & $\begin{array}{c}\text { Metodologia técnico-científica utilizada em } \\
\text { Biotecnologia moderna e Engenharia } \\
\text { genética }\end{array}$ & 14 & \\
\hline & Questões éticas & 29 & \\
\hline \multirow{4}{*}{$\begin{array}{c}\text { Biologia das } \\
\text { populações v.3 } \\
\text { Amabis e Martho, } \\
2009\end{array}$} & Engenharia Genética & 93 & \multirow[t]{4}{*}{306} \\
\hline & Biotecnologia moderna & 467 & \\
\hline & Biotecnologia moderna aplicada à saúde & 27 & \\
\hline & $\begin{array}{c}\text { Metodologia técnico-científica utilizada em } \\
\text { Biotecnologia moderna e Engenharia } \\
\text { genética }\end{array}$ & 10 & \\
\hline
\end{tabular}




\begin{tabular}{|c|c|c|c|}
\hline & Questões éticas & 9 & \\
\hline \multirow{4}{*}{$\begin{array}{l}\text { Novas bases da } \\
\text { Biologia v.3 } \\
\text { Bizzo, } 2012\end{array}$} & Engenharia Genética & 38 & \multirow{4}{*}{87} \\
\hline & Biotecnologia moderna & 43 & \\
\hline & Biossegurança & 1 & \\
\hline & $\begin{array}{c}\text { Metodologia técnico-científica utilizada em } \\
\text { Biotecnologia moderna e Engenharia } \\
\text { genética }\end{array}$ & 5 & \\
\hline \multirow{4}{*}{$\begin{array}{l}\text { Biologia Hoje v.3 } \\
\text { Linhares e } \\
\text { Gewandsznadjer, } \\
2011\end{array}$} & Engenharia Genética & 113 & \multirow{4}{*}{201} \\
\hline & Biotecnologia moderna & 76 & \\
\hline & Biotecnologia moderna aplicada à saúde & 7 & \\
\hline & $\begin{array}{c}\text { Metodologia técnico-científica utilizada em } \\
\text { Biotecnologia moderna e Engenharia } \\
\text { genética }\end{array}$ & 5 & \\
\hline \multirow{5}{*}{$\begin{array}{c}\text { Biologia: Ser } \\
\text { protagonista Biologia } \\
\text { v.3 } \\
\text { Santos et al.,2010 }\end{array}$} & Engenharia Genética & 54 & \multirow{5}{*}{123} \\
\hline & Biotecnologia moderna & 58 & \\
\hline & Biotecnologia moderna aplicada à saúde & 6 & \\
\hline & $\begin{array}{l}\text { Metodologia técnico-científica utilizada em } \\
\text { Biotecnologia moderna e Engenharia } \\
\text { genética }\end{array}$ & 2 & \\
\hline & Biossegurança & 3 & \\
\hline \multirow{5}{*}{$\begin{array}{c}\text { Biologia v.1 } \\
\text { Pezzi, Gowdak e } \\
\text { Mattos, } \\
2010\end{array}$} & Engenharia Genética & 42 & \multirow{5}{*}{109} \\
\hline & Biotecnologia moderna & 63 & \\
\hline & Biossegurança & 1 & \\
\hline & Biotecnologia moderna aplicada à saúde & 2 & \\
\hline & $\begin{array}{c}\text { Metodologia técnico-científica utilizada em } \\
\text { Biotecnologia moderna e Engenharia } \\
\text { genética }\end{array}$ & 1 & \\
\hline \multirow{4}{*}{$\begin{array}{c}\text { Biologia v.3 } \\
\text { Mendonça e } \\
\text { Laurence, } 2010\end{array}$} & Engenharia Genética & 41 & \multirow{4}{*}{124} \\
\hline & Biotecnologia moderna & 73 & \\
\hline & Biotecnologia moderna aplicada à saúde & 9 & \\
\hline & $\begin{array}{c}\text { Metodologia técnico-científica utilizada em } \\
\text { Biotecnologia moderna e Engenharia } \\
\text { genética }\end{array}$ & 1 & \\
\hline Total & - & - & 1.249 \\
\hline
\end{tabular}

Fonte: dados da investigação, 2014. 
As categorias Biotecnologia moderna e Engenharia genética foram as que mais se destacaram em termos de quantidade de número de registros. O livro de Amabis e Martho (2009) apresentou a maior quantidade de registros, seguido - em ordem decrescente - da obra de Lopes e Rosso (2010) e Linhares e Gewandsznadjer (2010). As obras de Mendonça e Laurence (2010), Santos et al. (2010), Pezzi, Gowdak e Mattos (2010) e Bizzo (2012) apresentaram quantidade de número de registro inferior a 150, o que leva a um caráter resumido do tema Biotecnologia e Engenharia genética nessas obras.

Quanto aos indicadores de enfoques, os resultados obtidos estão apresentados na Tabela 1.

Tabela 1. Indicadores de enfoque estabelecidos após análise de conteúdo dos livros didáticos selecionados.

\begin{tabular}{|c|c|}
\hline Indicador de enfoque & Frequência relativa (\%) \\
\hline \multicolumn{2}{|l|}{ Bio v.2. Lopes e Rosso, 2010} \\
\hline Enfoque relacionado a tecnologias de manipulação do DNA; & 82,94 \\
\hline Enfoque relacionado a questões éticas; & 9,70 \\
\hline Enfoque relacionado à genética humana e saúde; & 5,02 \\
\hline \multicolumn{2}{|l|}{ Biologia das populações v.3. Amabis e Martho, 2009} \\
\hline Enfoque relacionado a tecnologias de manipulação do DNA; & 88,24 \\
\hline Enfoque relacionado a questões éticas; & 2,94 \\
\hline Enfoque relacionado à genética humana e saúde; & 8,82 \\
\hline \multicolumn{2}{|l|}{ Novas bases da Biologia v.3. Bizzo, 2012} \\
\hline Enfoque relacionado a tecnologias de manipulação do DNA; & 98,85 \\
\hline Enfoque relacionado a questões éticas; & 1,15 \\
\hline \multicolumn{2}{|l|}{ Biologia hoje v.3. Linhares e Gewandsznadjer, 2011} \\
\hline Enfoque relacionado a tecnologias de manipulação do DNA; & 96,52 \\
\hline Enfoque relacionado à genética humana e saúde; & 3,48 \\
\hline \multicolumn{2}{|l|}{ Ser protagonista v.3. Santos et al. 2010} \\
\hline Enfoque relacionado a tecnologias de manipulação do DNA; & 92,68 \\
\hline Enfoque relacionado a questões éticas; & 2,44 \\
\hline Enfoque relacionado à genética humana e saúde; & 4,88 \\
\hline Biologia v.1. Pezzi, Gowdak e Mattos, 2010 & \\
\hline
\end{tabular}


Enfoque relacionado a tecnologias de manipulação do DNA; 97,30

Enfoque relacionado a questões éticas;

Enfoque relacionado à genética humana e saúde;

Biologia v.3. Mendonça e Laurence, 2010

Enfoque relacionado a tecnologias de manipulação do DNA;

Enfoque relacionado à genética humana e saúde; 7,26

Fonte: dados da investigação, 2014.

As obras de Lopes e Rosso (2010), Amabis e Martho (2010), Santos, Aguilar e Oliveira (2010) e Pezzi, Gowdak e Mattos (2010) apresentaram os três tipos de indicadores durante o desenvolvimento do tema ao longo do texto principal [Anexos A-D]. O enfoque predominante em todas as obras está relacionado às Técnicas e manipulação do DNA, onde todas estabeleceram uma frequência relativa acima dos $80 \%$, conforme apresentado na Tabela 1. As obras de Lopes e Rosso (2010), Amabis e Martho (2009), Bizzo (2012), Santos, Aguilar e Oliveira (2010) e Pezzi, Gowdak e Mattos (2010) foram as únicas a apresentarem o indicador Questões éticas, correspondendo a 9,63\%, 2,94\%, 1,15\%, 2,44\% e 0,9\% de frequência relativa, respectivamente.

A predominância do indicador "técnicas e manipulação do DNA" pode estar relacionada com a maior quantidade de unidades de registro que compõe as categorias estruturantes deste indicador. No entanto, chama-se a atenção para o indicador "Questões éticas", pois, atualmente, já é ciente da necessidade de um suporte ético para as pesquisas biotecnológicas atuais, principalmente pelo impacto que estas podem vir a causar na sociedade. Deve-se ser ciente também, da importância do livro didático como um dos materiais necessários para o processo de ensino-aprendizagem (VERCEZE; SILVINO, 2014). É perceptível à falta de importância que a maioria dos livros didáticos selecionados tem para com esse tema - ética - quando associado à Biotecnologia e Engenharia Genética. Segundo os PCN, no que diz respeito à contextualização sociocultural do aluno, "reconhecer e avaliar o caráter ético do conhecimento tecnológico e utilizar esses conhecimentos no exercício da cidadania" é uma competência necessária no ensino de Biologia e fundamental para 
formação do aluno. Sendo assim, faz-se importante a presença desses questionamentos nos livros didáticos de Biologia. Como já citado, apenas as obras de Lopes e Rosso (2010), Amabis e Martho (2009), Pezzi, Gowdak e Mattos (2010) e Santos, Aguilar e Oliveira (2010) apresentaram uma abordagem ética sobre o tema analisado.

\section{CONSIDERAÇÕES FINAIS}

A Biotecnologia se faz presente em muitos setores da sociedade. Desde a sua descoberta, a humanidade soube valorizar a importância e utilização dos seres vivos na Biotecnologia em função de beneficio próprio. Partindo desse sentido, o livro didático de Biologia é importante para os professores e alunos como uma ferramenta didática de fácil acesso para o ensino desse tema, o qual deve ser abordado de forma clara e objetiva, expondo argumentos, técnicas e conteúdos necessários para a sua compreensão. Tendo isso, o aluno estará de posse de uma ferramenta didática confiável, que lhe permite refletir e participar ativamente de assuntos relacionados à Biotecnologia e Engenharia genética, como também estar consciente dos progressos científicos desta área do conhecimento. Todos os livros apresentaram temas atuais que envolvem o conhecimento da Biologia, como técnicas e manipulação do DNA e aplicações das tecnologias do DNA na saúde, sendo a obra de Bizzo (2012) exceção para este último item. No entanto, foram às obras de Lopes e Rosso (2010) e Amabis e Martho (2009) que apresentaram uma abordagem significativa para aprendizagem do tema analisado.

Parte desses resultados parece ser um reflexo positivo da extensa bibliografia elaborada pelo governo federal - com auxílio de professores de todo o Brasil - a fim de nortear o ensino através de parâmetros e orientações curriculares. As escolas são as beneficiárias de todo este processo, pois cabe a elas escolher entre os títulos disponíveis, aqueles que melhor atendem ao seu projeto político pedagógico. Com isso, os resultados apresentados mostraram que os livros didáticos de Lopes e Rosso (2010) e Amabis e Martho (2009) que são os mais utilizados nas escolas de ensino médio do estado da Paraíba apresentam uma abordagem significativa para aprendizagem do tema analisado. Além disso, o livro didático é uma ferramenta que 
não deve ser trabalhada sozinha. Para que o educando seja capaz de construir o conhecimento associando ao seu cotidiano, faz-se necessária a presença do professormediador, pois este irá orienta-lo durante todo o processo de aprendizagem como também na utilização dos conteúdos disponíveis nos livros didáticos. A escolha de um bom livro didático de Biologia faz a diferença na alfabetização científica do educando, pois esta irá servir como uma ferramenta de acesso aos conhecimentos acumulados.

Por fim, os resultados obtidos neste trabalho podem ser utilizados para analisar outros temas referentes às outras disciplinas. Neste caso, como perspectiva de continuação do trabalho, outros temas presentes nos livros de Biologia como, por exemplo: Citologia, Ecologia, Genética, Zoologia, entre outros, podem ser analisados.

\section{AGRADECIMENTOS}

Primeiramente, agradecemos a Universidade Federal da Paraíba (UFPB). Por segundo, ao Professor Dr. Francisco José Pegado Abílio (CE/UFPB) por compartilhar de seu conhecimento em educação e por permitir o acesso ao seu acervo pessoal de livros didáticos. $E$ a todos que direta ou indiretamente fizeram parte da elaboração deste trabalho. 


\section{REFERÊNCIAS}

AMABIS, J. M.; MARTHO, G. R. Biologia das populações. v.3. São Paulo: Moderna, 2009.

BARDIN, L. Análise de Conteúdo. Lisboa: Edições 70, 2011.

BIZZO, N. Novas bases da Biologia: O ser humano e o futuro. v.3. São Paulo: Ática, 2012.

BORÉM, A. A história da Biotecnologia. Biotecnologia Ciência \& Desenvolvimento, Brasília/DF, n. 34, p. 10-12, 2005.

BRASIL, Ministério da Educação. Parâmetros Curriculares Nacionais (PCN): Ensino Médio. Brasília (DF), 2000.

CARVALHO, A. P. Ciência e Tecnologia no Brasil: a Capacitação Brasileira para a Pesquisa Científica e Tecnológica. 1. ed. Rio de Janeiro: Fundação Getúlio Vargas, 1996. p.19-21.

Figueiredo, L. H. M; PENTEAdO, M. I. O; MedeIROS, P. T. Patentes em Biotecnologia. Biotecnologia Ciência \& Desenvolvimento, Brasília/DF, n. 36, p. 32-39, 2006.

FUNDAÇÃO INSTITUTO BRASILEIRO DE GEOGRAFIA E ESTATÍSTICA. Pesquisa Nacional por Amostra de Domicílio (PNAD). Rio de Janeiro, 1982.

GIL, A. C. Como elaborar Projetos de Pesquisa. 4. ed. São Paulo: Atlas, 2002.

LINHARES, S; GEWANDSZNADJER, F. Biologia Hoje. v.3. São Paulo: Ática, 2011.

LOPES, S; ROSSO, S. Bio. v.2. São Paulo: Saraiva, 2010.

MALAJOVICH, M. A. Biotecnologia 2011. Rio de Janeiro: Biblioteca Max Feffer, 2012.

MARCONI, M. de A; LAKATOS, E. M. Fundamentos de Metodologia Científica. 7. ed. São Paulo: Atlas, 2010.

MENDONÇA, V; LAURENCE, J. Biologia. v.3. São Paulo: Nova Geração, 2010.

PEZZI, A. C; GOWDAK, D, O; MATTOS, N. S. Biologia: Citologia, Embriologia e Histologia. v.1. São Paulo: FTD, 2010.

SANTOS, F. S; AGUILAR, J. B. V; OLIVEIRA, M. M .A. de. Biologia: Ser Protagonista Biologia. v.3 São Paulo: Edições SM, 2010.

SILVA, S. N; CARVALHO, G. S. O ambiente em um livro didático de Biologia: Análise de Conteúdo. Em: Atas do VIII ENPEC/I CIEC. UNICAMP, Brasil. p. 1-13, 2012.

SILVEIRA, J. M. J; FUTINO, A. M; OLALDE, A. R. Biotecnologia: corporações, financiamento da inovação e novas formas organizacionais. Economia e Sociedade. Campinas, n. 18, 2002. 
TRIVIÑOS, A. N. S. Introdução à pesquisa em ciências sociais: a pesquisa qualitativa em educação. São Paulo: Atlas, 1987.

VERCEZE, R. M. A. N; SILVINO, E. F. M. O livro didático e suas implicações na prática do professor nas escolas públicas de Guajará-Mirim. Disponível em: <www.dtp.uem.br/rtpe/volumes/v11n3/010_rosa-338-347.pdf>. Acesso em: 5 nov. 2014. 


\section{ANEXO A - FICHA DE AVALIAÇÃO OBRA “BIO” DE LOPES E ROSSO (2010)}

\begin{tabular}{|c|c|c|c|c|c|}
\hline Categoria & $\begin{array}{c}\text { Componente de } \\
\text { registro }\end{array}$ & Exemplo & F.A & F.R (\%) & F.R (\%) \\
\hline \multirow{12}{*}{$\begin{array}{l}\text { Engenharia } \\
\text { genética }\end{array}$} & Célula vegetal & $\begin{array}{c}\text { "Assim, qualquer gene pode ser } \\
\text { introduzido em uma célula vegetal } \\
\text { utilizando-se essa ferramenta oferecida } \\
\text { pela própria natureza." }\end{array}$ & 1 & 0,33 & \multirow{12}{*}{32,78} \\
\hline & In vitro & $\begin{array}{c}\text { "Dessa forma originam-se vírus in vitro, ou } \\
\text { seja, em laboratório." }\end{array}$ & 3 & 1,00 & \\
\hline & Transgênico & $\begin{array}{l}\text { "Organismos transgênicos são aqueles } \\
\text { que recebem genes de outras espécies de } \\
\text { seres vivos." }\end{array}$ & 10 & 3,34 & \\
\hline & $\begin{array}{l}\text { Engenharia } \\
\text { genética }\end{array}$ & $\begin{array}{l}\text { "A engenharia genética possibilita a } \\
\text { manipulação de moléculas de DNA." }\end{array}$ & 6 & 2,01 & \\
\hline & Gene & $\begin{array}{c}\text { "[...] é possível produzir insulina clonando } \\
\text { gene humano em bactérias e estimulando } \\
\text { para entrar atividade." }\end{array}$ & 53 & 17,73 & \\
\hline & $\begin{array}{l}\text { Enzimas de } \\
\text { restrição }\end{array}$ & $\begin{array}{l}\text { "Cientistas conseguem isolar o DNA e } \\
\text { utilizando enzimas de restrição [...]." }\end{array}$ & 7 & 2,34 & \\
\hline & $\begin{array}{l}\text { Manipulação do } \\
\text { DNA }\end{array}$ & $\begin{array}{l}\text { "A descoberta dessas enzimas [de } \\
\text { restrição] permitiu grandes avanços na } \\
\text { manipulação do DNA." }\end{array}$ & 2 & 0,67 & \\
\hline & $\begin{array}{l}\text { DNA } \\
\text { recombinante }\end{array}$ & $\begin{array}{l}\text { "A molécula de DNA associada a novo } \\
\text { trecho é o DNA recombinante." }\end{array}$ & 5 & 1,67 & \\
\hline & OGM & $\begin{array}{c}\text { "Nas plantas, os métodos empregados } \\
\text { obtenção de organismos transgênicos } \\
\text { (geneticamente modificados - OGM) [...]." }\end{array}$ & 1 & 0,33 & \\
\hline & Anticorpos & $\begin{array}{c}\text { "O produto da atividade desses genes é } \\
\text { purificado e pode atuar como vacina, }[. . .] \\
\text { estimula a produção de anticorpos } \\
\text { específicos." }\end{array}$ & 1 & 0,33 & \\
\hline & Insulina & $\begin{array}{c}\text { "A produção de certos hormônios [...] já é } \\
\text { realizada por meio de técnicas de } \\
\text { clonagem, como a insulina [...]." }\end{array}$ & 8 & 2,68 & \\
\hline & Antibiótico & $\begin{array}{c}\text { "Nos plasmídeos estão, em geral, genes } \\
\text { que conferem às bactérias resistência a } \\
\text { antibióticos." }\end{array}$ & 1 & 0,33 & \\
\hline
\end{tabular}




\section{CONTINUAÇÃO DO ANEXO A}

\begin{tabular}{|c|c|c|c|c|c|}
\hline \multirow{13}{*}{$\begin{array}{l}\text { Biotecnologia } \\
\text { moderna }\end{array}$} & Microrganismo & $\begin{array}{c}\text { "Ao se reproduzir, esses microrganismos } \\
\text { multiplicam as moléculas recombinantes } \\
{[\ldots . .] . "}\end{array}$ & 1 & 0,33 & \multirow{13}{*}{45,15} \\
\hline & Genoma & $\begin{array}{l}\text { "Importante frisar que não se clonam } \\
\text { indivíduos, mas sim genomas, [...]." }\end{array}$ & 8 & 2,68 & \\
\hline & Cromossomo & $\begin{array}{l}\text { "Os cromossomos humanos contêm } \\
\text { cerca de } 35 \text { mil genes [...]." }\end{array}$ & 9 & 3,01 & \\
\hline & Análise do DNA & $\begin{array}{c}\text { "[...] identificação de pessoas com base } \\
\text { na análise do DNA [...." }\end{array}$ & 4 & 1,34 & \\
\hline & DNA & $\begin{array}{l}\text { "Os cientistas conseguem isolar DNA } \\
\text { viral e, utilizando enzimas [...]." }\end{array}$ & 66 & 22,07 & \\
\hline & $\begin{array}{l}\text { Biologia } \\
\text { Molecular }\end{array}$ & $\begin{array}{c}\text { "Usando técnicas Biologia Molecular, os } \\
\text { cientistas estão avançando em mais uma } \\
\text { área importante [...]." }\end{array}$ & 4 & 1,34 & \\
\hline & Clonagem & $\begin{array}{l}\text { "A produção de certos hormônios [...] já } \\
\text { tem sido realizada por meio de técnicas } \\
\text { de clonagem [...]." }\end{array}$ & 25 & 8,36 & \\
\hline & Células-tronco & $\begin{array}{l}\text { "[...] não é permitida por lei, mas a } \\
\text { clonagem terapêutica, que é feita com a } \\
\text { finalidade de produção de células- } \\
\text { tronco, sim." }\end{array}$ & 1 & 0,33 & \\
\hline & Laboratório & $\begin{array}{c}\text { "[...] insulina extraída do pâncreas de } \\
\text { ratos criados em laboratório[...]." }\end{array}$ & 4 & 1,34 & \\
\hline & $\begin{array}{l}\text { Biblioteca de } \\
\text { DNA }\end{array}$ & $\begin{array}{l}\text { "Clonando-se vários trechos das } \\
\text { moléculas de DNA de uma espécie, é } \\
\text { possível formar biblioteca de DNA." }\end{array}$ & 1 & 0,33 & \\
\hline & Proteoma & $\begin{array}{l}\text { "Proteoma é um termo relativa mente } \\
\text { novo, significa o conjunto de proteínas } \\
\text { expressas por um genoma." }\end{array}$ & 8 & 2,68 & \\
\hline & Biotecnologia & $\begin{array}{c}\text { "[...] a Biotecnologia corresponde a } \\
\text { técnicas que têm permitido ao ser } \\
\text { humano utilizar organismos para obter } \\
\text { produtos de seu interesse." }\end{array}$ & 4 & 1,34 & \\
\hline & Terapia gênica & $\begin{array}{c}\text { "Terapia gênica é área em expansão que } \\
\text { envolve essas técnicas." }\end{array}$ & 8 & 2,68 & \\
\hline
\end{tabular}




\section{CONTINUAÇÃO DO ANEXO A}

\begin{tabular}{|c|c|c|c|c|c|}
\hline \multirow{4}{*}{$\begin{array}{l}\text { Biotecnologia } \\
\text { moderna } \\
\text { aplicada à } \\
\text { saúde }\end{array}$} & Diagnóstico & $\begin{array}{c}\text { "Por meio dessa técnica também é } \\
\text { possível [...] para fazer diagnósticos } \\
\text { antes do nascimento." }\end{array}$ & 8 & 2,68 & \multirow{4}{*}{7,36} \\
\hline & $\begin{array}{l}\text { Doenças } \\
\text { genéticas }\end{array}$ & $\begin{array}{c}\text { "[...] as informações que podem ser } \\
\text { obtidas em diagnóstico pré-natal sobre } \\
\text { doenças genéticas em fetos." }\end{array}$ & 1 & 0,33 & \\
\hline & $\begin{array}{l}\text { Clonagem } \\
\text { terapêutica }\end{array}$ & $\begin{array}{l}\text { "[...] não é permitida por lei, mas a } \\
\text { clonagem terapêutica, que é feita com a } \\
\text { finalidade de produção de células- } \\
\text { tronco, sim." }\end{array}$ & 1 & 0,33 & \\
\hline & $\begin{array}{l}\text { Aconselhamento } \\
\text { genético }\end{array}$ & $\begin{array}{l}\text { "Os avanços na engenharia genética nos } \\
\text { últimos anos têm permitido [...] } \\
\text { melhorias no serviço de } \\
\text { aconselhamento genético." }\end{array}$ & 4 & 1,34 & \\
\hline \multirow{5}{*}{$\begin{array}{l}\text { Metodologia } \\
\text { técnico- } \\
\text { científica } \\
\text { utilizada em } \\
\text { Biotecnologia } \\
\text { moderna e } \\
\text { Engenharia } \\
\text { genética }\end{array}$} & Eletroforese & $\begin{array}{c}\text { "[...] quebrando o DNA, isolam-se } \\
\text { fragmentos de diferentes tamanhos, que } \\
\text { são separados por uma técnica chamada } \\
\text { eletroforese." }\end{array}$ & 2 & 0,67 & \multirow{5}{*}{5,02} \\
\hline & $\begin{array}{l}\text { Clonagem de } \\
\text { DNA }\end{array}$ & $\begin{array}{l}\text { "Clonagem de DNA significa produzir } \\
\text { inúmeras cópias idênticas de um mesmo } \\
\text { fragmento da molécula de DNA." }\end{array}$ & 2 & 0,67 & \\
\hline & PCR & $\begin{array}{l}\text { "A técnica da PCR foi desenvolvida em } \\
1985 \text { pelo bioquímico Kary Mulis." }\end{array}$ & 4 & 1,34 & \\
\hline & Amnioncentese & $\begin{array}{l}\text { "Com a amniocentese, obtêm-se as } \\
\text { mesmas informações que no exame das } \\
\text { vilosidades coriônicas [...]." }\end{array}$ & 1 & 0,33 & \\
\hline & DNA fingerprint & $\begin{array}{l}\text { "O DNA fingerprint tem sido útil para } \\
\text { identificação de pessoas, [...] sobre a } \\
\text { possível participação de suspeitos em } \\
\text { crimes e para testes de paternidade." }\end{array}$ & 6 & 2,01 & \\
\hline
\end{tabular}




\section{CONTINUAÇÃO DO ANEXO A}

\begin{tabular}{|c|c|c|c|c|c|}
\hline \multirow{5}{*}{$\begin{array}{l}\text { Questões } \\
\text { éticas }\end{array}$} & Religião & $\begin{array}{l}\text { "[...] a questão do aborto envolve } \\
\text { aspectos religiosos, éticos e morais que } \\
\text { merecem ampla discussão [...]." }\end{array}$ & 1 & 0,33 & \multirow{5}{*}{9,70} \\
\hline & Ética & $\begin{array}{c}\text { "A possibilidade de clonagem, inclusive a } \\
\text { humana, tem levantado intensas } \\
\text { discussões éticas." }\end{array}$ & 19 & 6,35 & \\
\hline & Bioética & $\begin{array}{l}\text { "[...] Bioética são formas novas da ética } \\
\text { aplicada que caracterizam a sociedade, a } \\
\text { cultura e os valores morais da civilização } \\
\text { contemporânea." }\end{array}$ & 6 & 2,01 & \\
\hline & Ecoética & $\begin{array}{l}\text { "A Ecoética e a Bioética são formas } \\
\text { novas da ética aplicada que caracterizam } \\
\text { a sociedade, a cultura e os valores } \\
\text { morais da civilização contemporânea." }\end{array}$ & 1 & 0,33 & \\
\hline & Moral & $\begin{array}{l}\text { "[...] a questão do aborto envolve } \\
\text { aspectos religiosos, éticos e morais que } \\
\text { merecem ampla discussão [...]." }\end{array}$ & 2 & 0,67 & \\
\hline Total & & & & & 100 \\
\hline
\end{tabular}

Fonte: Dados da investigação, 2014. 


\section{ANEXO B - FICHA DE AVALIAÇÃO \\ OBRA “BIOLOGIA DAS POPULAÇõES” DE AMABIS E MARTHO (2010)}

\begin{tabular}{|c|c|c|c|c|c|}
\hline Categoria & $\begin{array}{l}\text { Componente } \\
\text { de registro }\end{array}$ & Exemplo & F.A & $\begin{array}{l}\text { F.R } \\
(\%)\end{array}$ & $\begin{array}{l}\text { F.R } \\
\text { (\%) }\end{array}$ \\
\hline \multirow{9}{*}{$\begin{array}{l}\text { Engenharia } \\
\text { Genética }\end{array}$} & Gene & $\begin{array}{c}\text { "[...] a capacidade de resistir a doenças } \\
\text { etc., são condicionadas por genes que } \\
\text { interagem fortemente com fatores } \\
\text { ambientais." }\end{array}$ & 45 & 14,71 & \multirow{9}{*}{30,39} \\
\hline & Híbrido & $\begin{array}{l}\text { " Essas plantas foram denominadas } \\
\text { híbridas, termo utilizado também para } \\
\text { designar o produto do cruzamento entre } \\
\text { linhagens diferentes [...]." }\end{array}$ & 6 & 1,96 & \\
\hline & $\begin{array}{l}\text { DNA } \\
\text { recombinante }\end{array}$ & $\begin{array}{l}\text { " cortar o DNA de plasmídeos, emendá-lo a } \\
\text { um outro DNA e introduzir a molécula } \\
\text { produzida - DNA recombinante - [...]." }\end{array}$ & 4 & 1,31 & \\
\hline & $\begin{array}{l}\text { Enzimas de } \\
\text { restrição }\end{array}$ & $\begin{array}{c}\text { " As enzimas de restrição são enzimas } \\
\text { bacterianas que atuam como "tesouras } \\
\text { moleculares [...]." }\end{array}$ & 14 & 4,58 & \\
\hline & Antibiótico & $\begin{array}{l}\text { " Cohen trabalhava com plasmídeos } \\
\text { bacterianos, tentando isolar genes para } \\
\text { resistência a antibióticos." }\end{array}$ & 1 & 0,33 & \\
\hline & $\begin{array}{l}\text { Engenharia } \\
\text { genética }\end{array}$ & $\begin{array}{l}\text { " As técnicas da engenharia genética } \\
\text { tornaram possível introduzir um gene } \\
\text { humano em um camundongo." }\end{array}$ & 6 & 1,96 & \\
\hline & In vitro & $\begin{array}{c}\text { " [...] é necessário fazer a fecundação in } \\
\text { vitro [...]." }\end{array}$ & 1 & 0,33 & \\
\hline & Insulina & $\begin{array}{l}\text { " A insulina foi a primeira proteína humana } \\
\text { produzida por engenharia genética." }\end{array}$ & 5 & 1,63 & \\
\hline & Transgênicos & $\begin{array}{l}\text { "Os organismos que recebem e } \\
\text { incorporam genes de outra espécie são } \\
\text { chamados de transgênicos." }\end{array}$ & 11 & 3,59 & \\
\hline
\end{tabular}




\section{CONTINUAÇÃO DO ANEXO B}

\begin{tabular}{|c|c|c|c|c|c|}
\hline \multirow{11}{*}{$\begin{array}{l}\text { Biotecnologia } \\
\text { Moderna }\end{array}$} & DNA & $\begin{array}{l}\text { "[...] sequências de pares de bases } \\
\text { específicas em moléculas de DNA." }\end{array}$ & 81 & 26,47 & \multirow{11}{*}{54,58} \\
\hline & Microrganismo & $\begin{array}{l}\text { "[...] microrganismos que constituem } \\
\text { nossos alimentos básicos foram } \\
\text { domesticadas e "melhoradas" em } \\
\text { diferentes regiões do mundo." }\end{array}$ & 1 & 0,33 & \\
\hline & Melhoramento & $\begin{array}{c}\text { "O melhoramento consiste em selecionar e } \\
\text { aprimorar as qualidades das espécies tendo } \\
\text { em vista usa utilização pelos seres } \\
\text { humanos." }\end{array}$ & 5 & 1,63 & \\
\hline & $\begin{array}{l}\text { Genética } \\
\text { molecular }\end{array}$ & $\begin{array}{c}\text { "[...] a descoberta das enzimas de restrição } \\
\text { permitiu um grande avanço na Genética } \\
\text { Molecular." }\end{array}$ & 2 & 0,65 & \\
\hline & Análise do DNA & $\begin{array}{l}\text { "É cada vez maior o número de genes } \\
\text { deletérios identificados pelas novas } \\
\text { técnicas de análise do DNA [...]." }\end{array}$ & 1 & 0,33 & \\
\hline & Cromossomos & $\begin{array}{l}\text { " A região mediana do cromossomo, onde } \\
\text { se localiza os genes não essenciais [...]." }\end{array}$ & 22 & 7,19 & \\
\hline & PGH & $\begin{array}{l}\text { " O Projeto Genoma Humano teve início } \\
\text { oficialmente em outubro de } 1990 \text { [...]." }\end{array}$ & 8 & 2,61 & \\
\hline & Fungo & $\begin{array}{c}\text { "[...] um segmento de DNA plasmidial capaz } \\
\text { de se multiplicar em células da levedura, } \\
\text { comportando-se como um dos } \\
\text { cromossomos desse fungo." }\end{array}$ & 1 & 0,33 & \\
\hline & $\begin{array}{l}\text { Biologia } \\
\text { molecular }\end{array}$ & $\begin{array}{c}\text { "Até agora o genoma completo de mais de } \\
25 \text { organismos microbianos foram } \\
\text { sequenciados, incluindo a E. coli, na qual a } \\
\text { Biologia Molecular [...]." }\end{array}$ & 1 & 0,33 & \\
\hline & Genômica & $\begin{array}{c}\text { "[...] a era da análise genômica representa } \\
\text { um novo começo [...]." }\end{array}$ & 11 & 3,59 & \\
\hline & Genoma & $\begin{array}{l}\text { " Agora que o genoma de vários } \\
\text { organismos inferiores foi totalmente } \\
\text { sequenciado [...]." }\end{array}$ & 34 & 11,11 & \\
\hline
\end{tabular}




\section{CONTINUAÇÃO DO ANEXO B}

\begin{tabular}{|c|c|c|c|c|c|}
\hline \multirow{5}{*}{$\begin{array}{l}\text { Biotecnologia } \\
\text { moderna } \\
\text { aplicada à } \\
\text { saúde }\end{array}$} & $\begin{array}{l}\text { Doenças } \\
\text { genéticas }\end{array}$ & $\begin{array}{c}\text { " preocupar em procurar } \\
\text { aconselhamento genético se já teve } \\
\text { alguma criança [...] afetados por doenças } \\
\text { genéticas." }\end{array}$ & 8 & 2,61 & \multirow{5}{*}{8,82} \\
\hline & Exame & $\begin{array}{l}\text { " costuma-se realizar exame de DNA de } \\
\text { uma célula dos embriões antes da } \\
\text { implantação no útero da mãe." }\end{array}$ & 6 & 1,96 & \\
\hline & Diagnóstico & $\begin{array}{l}\text { " Atualmente é possível diagnosticar } \\
\text { certas doenças genéticas graves ainda } \\
\text { durante a vida intra-uterina." }\end{array}$ & 5 & 1,63 & \\
\hline & Geneterapia & $\begin{array}{c}\text { " [...] geneterapia. Teoricamente, seria } \\
\text { possível substituir ou adicionar na } \\
\text { pessoa doente uma copia correta do } \\
\text { alelo alterado [...]." }\end{array}$ & 3 & 0,98 & \\
\hline & $\begin{array}{l}\text { Aconselhamento } \\
\text { genético }\end{array}$ & $\begin{array}{c}\text { " preocupar em procurar } \\
\text { aconselhamento genético se já teve } \\
\text { alguma criança [...] afetados por doenças } \\
\text { genéticas." }\end{array}$ & 5 & 1,63 & \\
\hline \multirow{2}{*}{$\begin{array}{l}\text { Metodologia } \\
\text { técnico- } \\
\text { científica } \\
\text { utilizada em } \\
\text { Biotecnologia } \\
\text { moderna e } \\
\text { Engenharia } \\
\text { genética }\end{array}$} & $\begin{array}{l}\text { Clonagem } \\
\text { molecular }\end{array}$ & $\begin{array}{c}\text { [...] multiplicação da célula bacteriana } \\
\text { transformada, constitui um clone } \\
\text { molecular, daí a metodologia para obtê- } \\
\text { lo ser denominada clonagem } \\
\text { molecular." }\end{array}$ & 8 & 2,61 & \multirow[t]{2}{*}{3,27} \\
\hline & Eletroforese & $\begin{array}{c}\text { " [...] os fragmentos obtidos na reação } \\
\text { de sequenciamento, o que é feito por } \\
\text { meio da técnica de eletroforese." }\end{array}$ & 2 & 0,65 & \\
\hline \multirow[t]{2}{*}{$\begin{array}{l}\text { Questões } \\
\text { éticas }\end{array}$} & Moral & $\begin{array}{c}\text { "Os conhecimentos biológicos têm } \\
\text { afetado cada vez mais a vida das } \\
\text { pessoas, seja pelas possibilidades de sua } \\
\text { aplicação nos campos da produção de } \\
\text { alimentos e da saúde, seja pelos } \\
\text { conflitos morais e éticos decorrentes } \\
\text { [...]." }\end{array}$ & 3 & 0,98 & \multirow[t]{2}{*}{2,94} \\
\hline & Ética & $\begin{array}{c}\text { "Apesar da metodologia ainda não ser } \\
\text { realidade, muitos já se preocupam com } \\
\text { os problemas éticos que ela pode } \\
\text { trazer." }\end{array}$ & 6 & 1,96 & \\
\hline \multicolumn{5}{|l|}{ Total } & 100 \\
\hline
\end{tabular}

Fonte: Dados da investigação, 2014. 
ANEXO C - FICHA DE AVALIAÇÃO

OBRA “BIOLOGIA: SER PROTAGONISTA” DE SANTOS, AGUILAR E OLIVEIRA (2010)

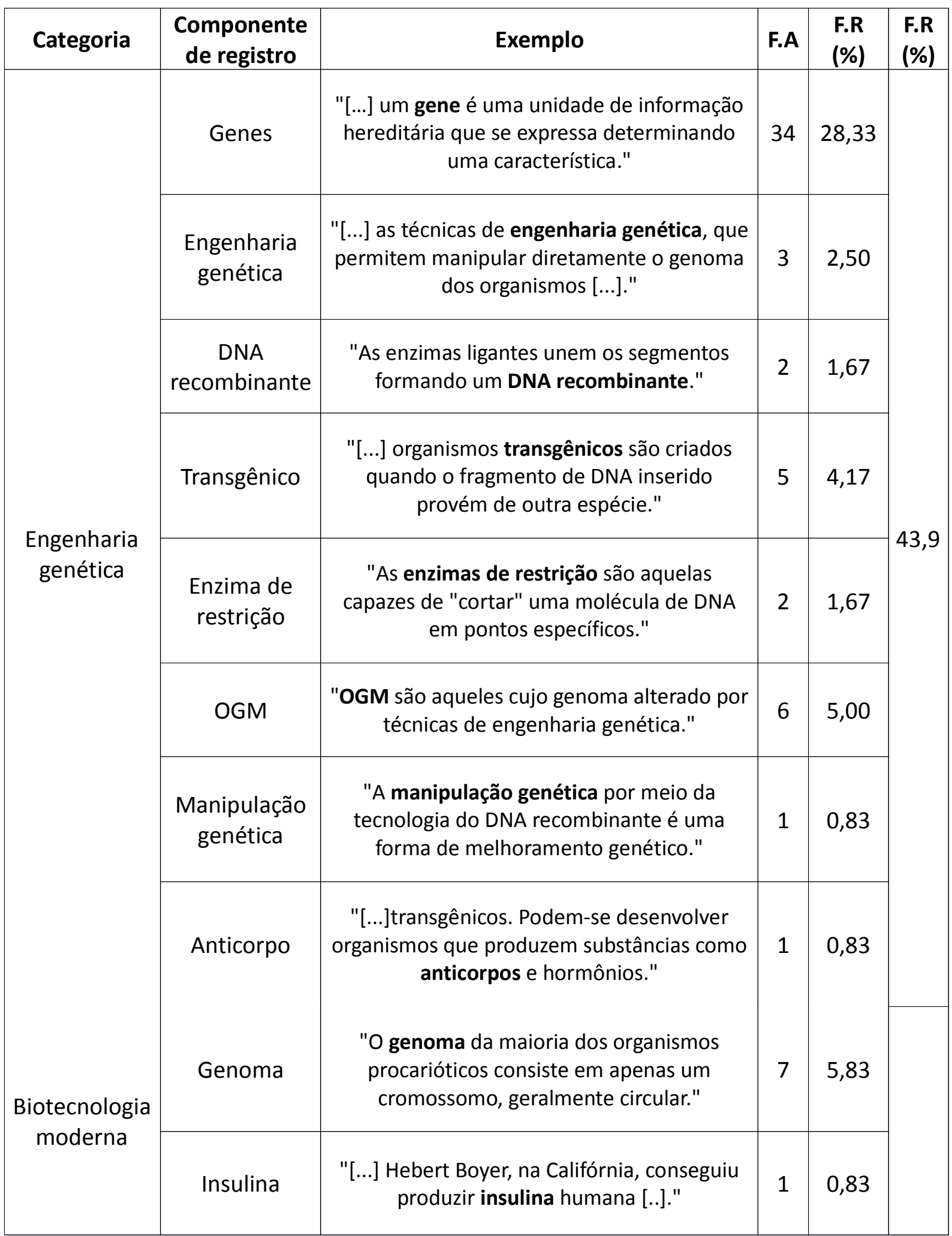




\section{CONTINUAÇÃO DO ANEXO C}

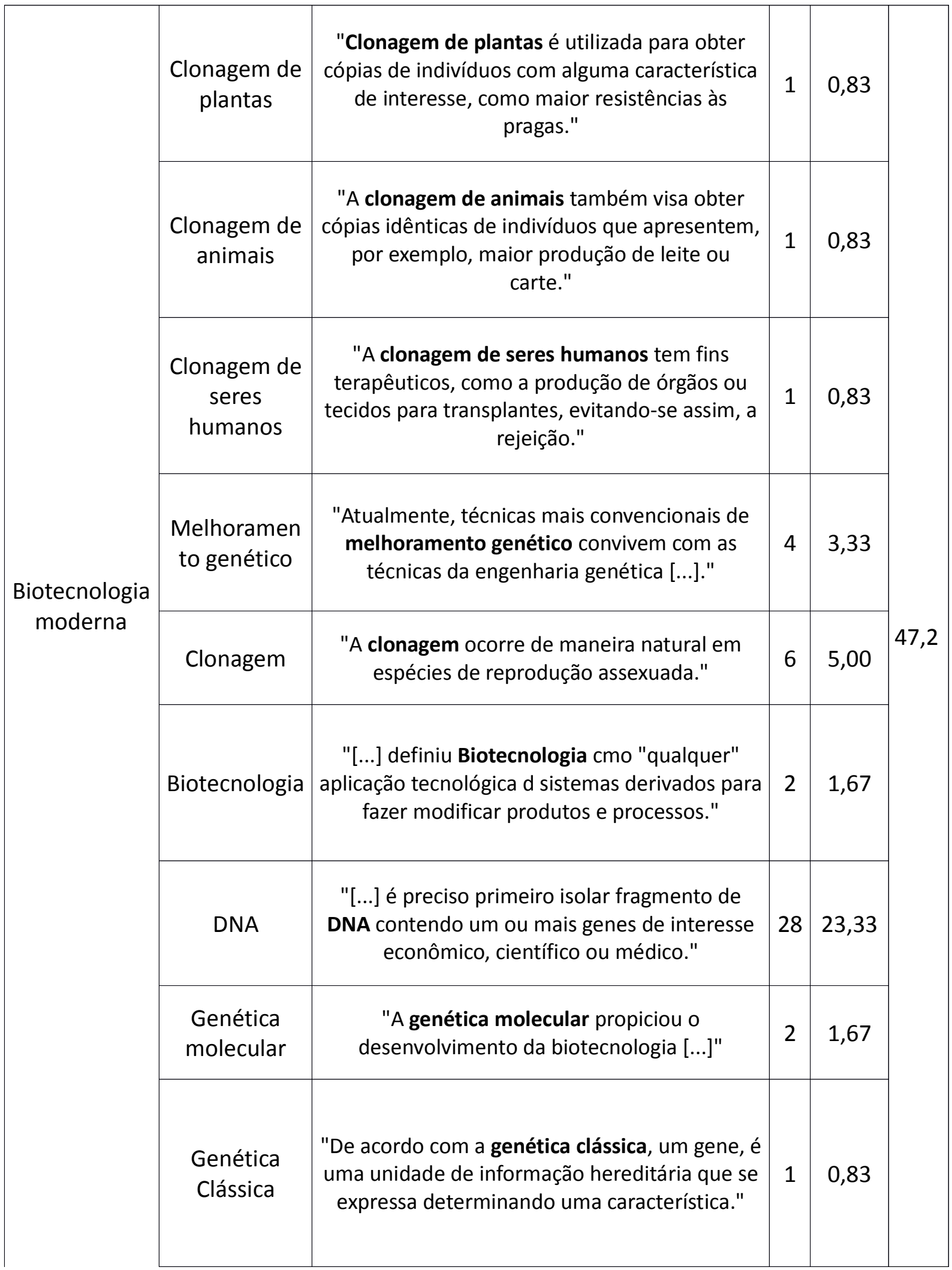




\section{CONTINUAÇÃO DO APÊNDICE C}

\begin{tabular}{|c|c|c|c|c|c|}
\hline \multirow{3}{*}{$\begin{array}{l}\text { Biotecnologia } \\
\text { moderna }\end{array}$} & Laboratório & $\begin{array}{c}\text { "[...] técnicas da engenharia genética, que } \\
\text { permitem manipular diretamente o } \\
\text { genoma dos organismos e também } \\
\text { construir sequências de DNA em } \\
\text { laboratório." }\end{array}$ & 1 & 0,83 & \\
\hline & Cromossomo & $\begin{array}{l}\text { "O genoma da maioria dos organismos } \\
\text { procarióticos consiste em apenas um } \\
\text { cromossomo, geralmente circular." }\end{array}$ & 2 & 1,67 & \\
\hline & Embrapa & $\begin{array}{l}\text { "Esses OGM foram desenvolvidos pela } \\
\text { Embrapa, um dos centros de excelência no } \\
\text { melhoramento genético animal e vegetal." }\end{array}$ & 1 & 0,83 & \\
\hline \multirow{2}{*}{$\begin{array}{l}\text { Biotecnologia } \\
\text { moderna } \\
\text { aplicada à } \\
\text { saúde }\end{array}$} & $\begin{array}{l}\text { Doença } \\
\text { genética }\end{array}$ & $\begin{array}{l}\text { "Após localizar um gene envolvido na } \\
\text { expressão de uma doença genética é } \\
\text { possível estudar sua sequência de DNA e } \\
\text { seu produto proteico." }\end{array}$ & 1 & 0,83 & \multirow{2}{*}{4,9} \\
\hline & Terapia gênica & $\begin{array}{l}\text { "Com a compreensão dos mecanismos } \\
\text { genéticos e moleculares de uma doença, é } \\
\text { possível desenvolver a terapia gênica." }\end{array}$ & 5 & 4,17 & \\
\hline $\begin{array}{l}\text { Metodologia } \\
\text { técnico- } \\
\text { científica } \\
\text { utilizada em } \\
\text { Biotecnologia } \\
\text { moderna e } \\
\text { Engenharia } \\
\text { genética }\end{array}$ & Eletroforese & $\begin{array}{l}\text { "Uma molécula de DNA cortada com } \\
\text { determinado tipo de enzima de restrição } \\
\text { fornece pedações de DNA que podem ser } \\
\text { separados de acordo com o seu tamanho e } \\
\text { carga elétrica, por meio da eletroforese." }\end{array}$ & 2 & 1,67 & 1,67 \\
\hline \multirow[t]{2}{*}{ Biossegurança } & CTNBio & $\begin{array}{c}\text { "Essa lei determina que as variedades de } \\
\text { transgênicos sejam analisadas e aprovadas } \\
\text { por duas comissões antes de ser } \\
\text { produzidas em escala comercial: CTNBio e } \\
\text { o CNBS. }\end{array}$ & 1 & 0,83 & \multirow[t]{2}{*}{2,4} \\
\hline & Biossegurança & $\begin{array}{l}\text { "No Brasil, a regulamentação para } \\
\text { produção e comercialização de } \\
\text { transgênicos é estabelecida pela Lei de } \\
\text { Biossegurança [...]." }\end{array}$ & 2 & 1,67 & \\
\hline \multicolumn{5}{|l|}{ Total } & 100 \\
\hline
\end{tabular}

Fonte: Dados da investigação, 2014. 


\section{ANEXO D - FICHA DE AVALIAÇÃO \\ OBRA “BIOLOGIA” DE PEZZI, GOWDAK E MATTOS (2010)}

\begin{tabular}{|c|c|c|c|c|c|}
\hline Categoria & $\begin{array}{l}\text { Componente } \\
\text { de registro }\end{array}$ & Exemplo & F.A & F.R (\%) & F.R (\%) \\
\hline \multirow{7}{*}{$\begin{array}{l}\text { Engenharia } \\
\text { genética }\end{array}$} & $\begin{array}{l}\text { Engenharia } \\
\text { genética }\end{array}$ & $\begin{array}{c}\text { "A palavra associada principalmente a } \\
\text { atividades relacionadas à Engenharia } \\
\text { genética." }\end{array}$ & 4 & 3,6 & \multirow{10}{*}{37,84} \\
\hline & Genes & $\begin{array}{l}\text { "Genes que determinam características } \\
\text { desejadas são utilizados melhoramento } \\
\text { genético de muitas espécies." }\end{array}$ & 22 & 19,8 & \\
\hline & $\begin{array}{l}\text { Enzimas de } \\
\text { restrição }\end{array}$ & $\begin{array}{c}\text { " Enzimas de restrição, descobertas no inicio } \\
\text { da década de 1970, são capazes de cortar } \\
\text { molécula de DNA em determinados pontos, } \\
\text { de modo controlável." }\end{array}$ & 4 & 3,6 & \\
\hline & $\begin{array}{l}\text { DNA } \\
\text { recombinante }\end{array}$ & $\begin{array}{l}\text { " A técnica do DNA recombinante consiste } \\
\text { em extrair de bactérias os seus plasmídeos, } \\
\text { ou seja, pequenos anéis de DNA espalhados, } \\
\text { ou seja, pequenos anéis de DNA espalhados } \\
\text { no citoplasma." }\end{array}$ & 5 & 4,5 & \\
\hline & OGM & $\begin{array}{l}\text { "[...] um organismo que recebe genes de } \\
\text { outra espécie é [...], isto é, um OGM." }\end{array}$ & 1 & 0,9 & \\
\hline & Transgênico & $\begin{array}{c}\text { "[...] um organismo que recebe genes de } \\
\text { outra espécie é um transgênico [...]" }\end{array}$ & 5 & 4,5 & \\
\hline & Insulina & $\begin{array}{c}\text { " Em 1976, uma empresa de engenharia } \\
\text { genética conseguiu produzir uma proteína } \\
\text { humana, a insulina, por meio de uma } \\
\text { bactéria [...]." }\end{array}$ & 1 & 0,9 & \\
\hline \multirow{3}{*}{$\begin{array}{c}\text { Biotecnologia } \\
\text { moderna }\end{array}$} & Cromossomos & $\begin{array}{l}\text { "Já foram localizados os cromossomos e } \\
\text { genes responsáveis por muitas doenças } \\
\text { hereditárias da espécie humana [...]." }\end{array}$ & 1 & 0,9 & \\
\hline & Clonagem & $\begin{array}{l}\text { " A técnica de clonagem ainda é altamente } \\
\text { experimental, difícil de ser realizada e ainda } \\
\text { não liberada no Brasil." }\end{array}$ & 4 & 3,6 & \\
\hline & $\begin{array}{l}\text { Genética } \\
\text { molecular }\end{array}$ & $\begin{array}{c}\text { " As descobertas da genética molecular, } \\
\text { posteriores ao conhecimento da molécula do } \\
\text { DNA, principalmente técnicas de sua } \\
\text { manipulação, permitiram o desenvolver [...] } \\
\text { da engenharia genética." }\end{array}$ & 1 & 0,9 & \\
\hline
\end{tabular}




\section{CONTINUAÇÃO DO ANEXO D}

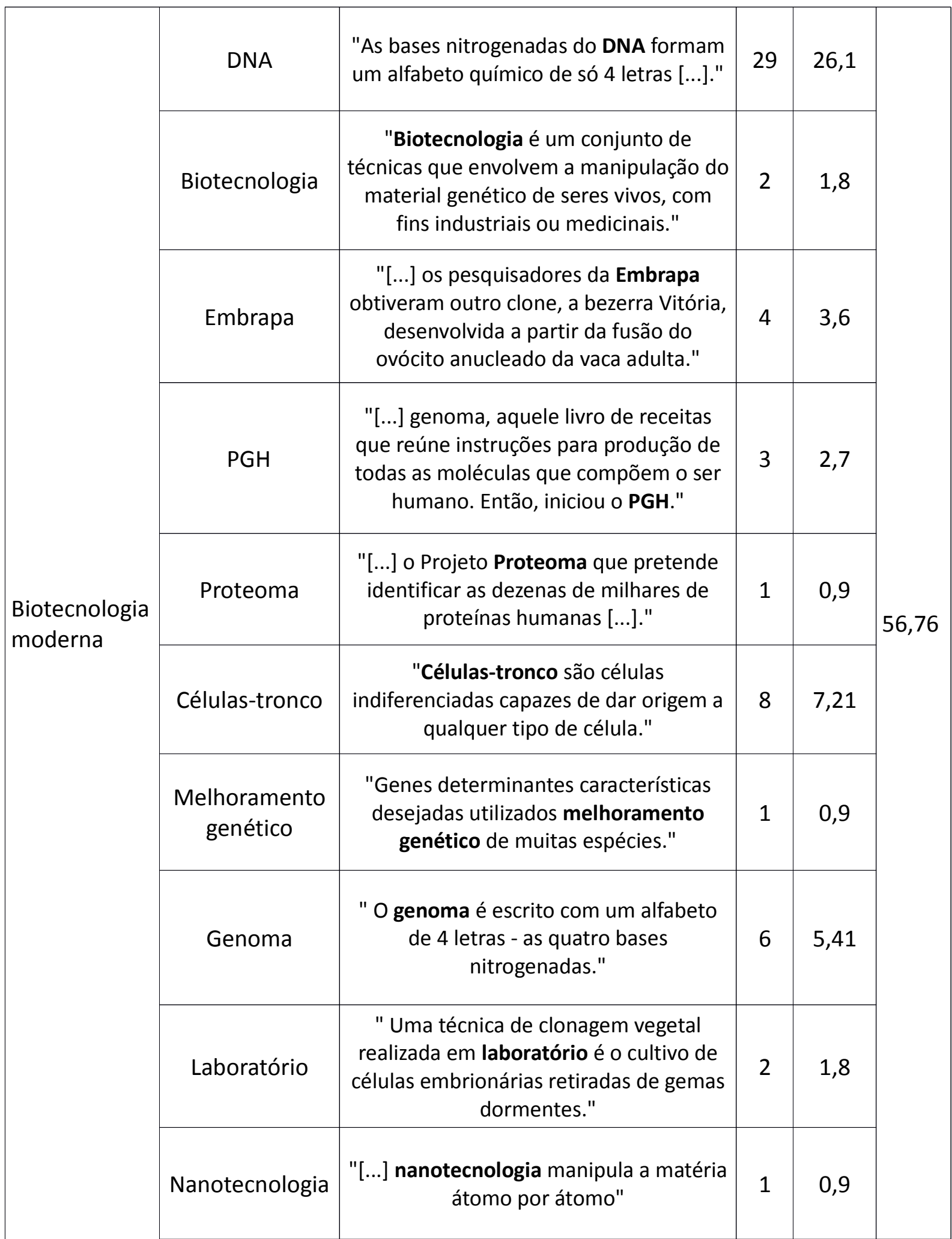




\section{CONTINUAÇÃO DO ANEXO D}

\begin{tabular}{|c|c|c|c|c|c|}
\hline \multirow[t]{2}{*}{$\begin{array}{l}\text { Biotecnologia } \\
\text { moderna } \\
\text { aplicada na } \\
\text { saúde }\end{array}$} & Terapia gênica & $\begin{array}{c}\text { "A terapia gênica será responsável pela } \\
\text { substituição de genes defeituosos, por } \\
\text { outros normais [...]" }\end{array}$ & 1 & 0,9 & \multirow{2}{*}{2,70} \\
\hline & $\begin{array}{c}\text { Vacinas de } \\
\text { DNA }\end{array}$ & $\begin{array}{l}\text { "Vacinas de DNA, como a anunciada para a } \\
\text { prevenção e cura da tuberculoso, também } \\
\text { utilizam a técnica do DNA recombinante." }\end{array}$ & 1 & 0,9 & \\
\hline Biossegurança & Biossegurança & $\begin{array}{l}\text { " A nova lei Brasileira de Biossegurança } \\
\text { libera, apenas, o uso de embriões } \\
\text { congelados nas clínicas de fertilidade há } \\
\text { mais de } 3 \text { anos e doados pelos genitores." }\end{array}$ & 1 & 0,9 & 0,9 \\
\hline $\begin{array}{l}\text { Metodologia } \\
\text { técnico- } \\
\text { científica } \\
\text { utilizada em } \\
\text { Biotecnologia } \\
\text { moderna e } \\
\text { Engenharia } \\
\text { genética }\end{array}$ & $\begin{array}{c}\text { DNA } \\
\text { fingerprint }\end{array}$ & $\begin{array}{c}\text { " O método do DNA fingerprint ou } \\
\text { impressão digital de DNA, utilizado pela } \\
\text { medicina e pela justiça para identificação } \\
\text { individual e reconhecimento de } \\
\text { paternidade [...]." }\end{array}$ & 3 & 2,7 & 2,70 \\
\hline \multicolumn{5}{|l|}{ Total } & 100 \\
\hline
\end{tabular}

Fonte: Dados da investigação, 2014. 